\title{
Environmental Deterioration of the Tecomate Coastal Lagoon, in the Guerrero State, Mexico
}

\author{
Salvador Villerías-Salinas ${ }^{1 *}$, Juan Violante-González ${ }^{2}$, Neftalí García-Castro' ${ }^{1}$, \\ Lorena Alonzo-Guzmán ${ }^{3}$ \\ ${ }^{1}$ Centro de Estudios y Posgrado en Estudios Socioterritoriales, Universidad Autónoma de Guerrero, \\ Chilpancingo, México \\ ${ }^{2}$ Unidad Académica de Ecología Marina, Universidad Autónoma de Guerrero, Acapulco, México \\ ${ }^{3}$ Unidad Académica de Ingeniería, Universidad Autónoma de Guerrero, Chilpancingo, México \\ Email: "svilleriass@gmail.com
}

Received 15 September 2015; accepted 10 January 2016; published 13 January 2016

Copyright (C) 2016 by authors and Scientific Research Publishing Inc.

This work is licensed under the Creative Commons Attribution International License (CC BY).

http://creativecommons.org/licenses/by/4.0/

(c) (i) Open Access

\section{Abstract}

An exhaustive field study was undertaken between November 2011 and August 2012, with the aim to know the causes of the environmental deterioration of the Tecomate Lagoon, in the Guerrero state, Mexico. Data of temperature, dissolved oxygen, salinity parameters and depth of the lagoon were interpolated using the Kriging geostatistical method to generate a prediction surface. The lagoon registered a great variation in its saline concentration, which ranged from 8.0 to $65.0 \mathrm{ppt}$, with the lowest values in November 2011 and the highest at May 2012. The great variability in the salinity throughout the year contributed in significant form to the lagoon's instability. An average water temperature of $32^{\circ} \mathrm{C}$ and dissolved oxygen levels of 4.49 to $7.44 \mathrm{mg} / \mathrm{L}$ were recorded. The low depth registered in the lagoon (mean $=1 \mathrm{~m}$ ), is related to fluvial and marine processes, both of which modify depth through the transport of sediment to its interior. Currently, fishing is scarce, with the mangrove forest in some areas in a process of deterioration due to a lack of moisture. The lagoon system is undergoing a process of environmental deterioration, with an advanced ecological succession and non-aquatic vegetable species colonizing the area surrounding the lagoon.

\section{Keywords}

Tecomate Lagoon, Environmental Parameters, Habitat Deterioration, Aquatic Ecosystem

${ }^{*}$ Corresponding author.

How to cite this paper: Villerías-Salinas, S., Violante-González, J., García-Castro, N. and Alonzo-Guzmán, L. (2016) Environmental Deterioration of the Tecomate Coastal Lagoon, in the Guerrero State, Mexico. International Journal of Geosciences, 7, 1-10. http://dx.doi.org/10.4236/ijg.2016.71001 


\section{Introduction}

Coastal lagoons rank among the most productive ecosystems on Earth, and they provide a wide range of ecosystem services and resources. They have a rich biodiversity of organisms due to their position between river drainages, and the continental shelf [1]. These aquatic ecosystems are used for breeding, protection and feeding for many fish species of different origin [2]. In tropical regions, the coastal lagoons are surrounded by a wide mangrove fringe [3]; this vegetation plays an important role in the diversity conservation, and as regulator of biogeochemical, and ecological cycles. The hydrological dynamic is related to the rivers that flow into the basin, and with the local climate regimen [4] [5].

These ecosystems are dynamic and vary seasonally, which influences the presence of organisms from marine or freshwater origin and creates an environment that is critical for commercially important species such as molluscs, crustaceans, and fishes [1].

The increase in salinity is associated with the opening of the bars and influences the composition of zooplankton. The recovery of this community depends on the speed with which the salinity is able to return to its normal level [6]. The environmental factors that have a higher influence in coastal lagoons, are the salinity, temperature, and dissolved oxygen, which has an important effect on the primary production. These environmental changes can affect the abundance and biodiversity composition of these water bodies [7]. Tecomate lagoon is a water body considered as a depression due to its internal banks on the continental margin [8]. It has an ephemeral communication with the sea, and is separated by a sand barrier that exerts a special geohydrodynamic effect. As is pointed out for [9], the geomorphological processes of the Pacific Mexican lagoons are at a high evolution level, in which the transport of terrigenous and marine sediments has a great influence in the dynamics of the lagoon. Surveys on coastal lagoons of Guerrero state are scarce [10]-[14] and today none exist on the Tecomate lagoon.

The objective of the present study was to evaluate the anthropogenic environmental impact, and analyzes the possible causes of the environmental deterioration in Tecomate lagoon, by means of the evaluation of some physical-chemical parameters, and bathymetry of the lagoon.

\section{Materials and Methods}

Tecomate Lagoon $\left(16^{\circ} 38^{\prime} 52^{\prime \prime} \mathrm{N}, 99^{\circ} 39^{\prime} 12^{\prime \prime} \mathrm{W}\right)$ is located approximately $50 \mathrm{~km}$ southeast from Acapulco City, in the Costa Chica region of the Guerrero state, Mexico. This lagoon have a surface of around $28 \mathrm{~km}^{2}$, is situated $11 \mathrm{~km}$ south of the San Marcos locality. The depth of the lagoon was determined manually using a ruler graduated in centimeters, while, to determine the vertical level of the water, the maximum and minimum heights reached in the period studied were considered. Data of physicochemical variables were obtained during November 2011 to August 2012 period, from 24 sampling stations geo-referenced with a Global Position System (GPS). The oxygen and temperature parameters were determined in situ using a YSI digital reader, model 55-12FT. Salinity was measured on a scale of 0 - 100 ppt with an ATAGO refractometer. The samples were taken during the day and at a depth of $0.40 \mathrm{~m}$. The map of the lagoon was prepared with digital ortophotographs, scale 1:75,000, processed by the Instituto Nacional de Estadística, Geografía e Informática (INEGI) [15] [16]. Moreover, the software ArcGis 10.0 [17] was used to prepare the synthetic cartography of the physicochemical parameters and bathymetry. The information was analyzed using a geostatistical method (Kriging), which generates a surface estimate from a series of dispersed points with values $\mathrm{z}$. The generated model is based on the statistical relationships between the points measured. At the same time, a variance analysis (ANOVA) of the four variables (depth, temperature, salinity, and dissolved oxygen) was conducted to observe the variation among the variables and groups.

\section{Results}

\subsection{The Environment Parameters}

The predominate climate in the area studied is warm sub-humid $\left(\mathrm{Aw}_{\mathrm{o}}\right)$, with the rainy season occurring in the summer and characterized by temperatures above $18^{\circ} \mathrm{C}$ and an average annual precipitation of 800 to $1200 \mathrm{~mm}$, whose highest level is registered during the summer. In the months of January and May, the average monthly environmental temperature in this geographical area increased from $32.1^{\circ} \mathrm{C}$ to $33.8^{\circ} \mathrm{C}$, with the highest temperatures recorded before the summer solstice (Figure 1). The geological origin of this region is morphotectonic and 


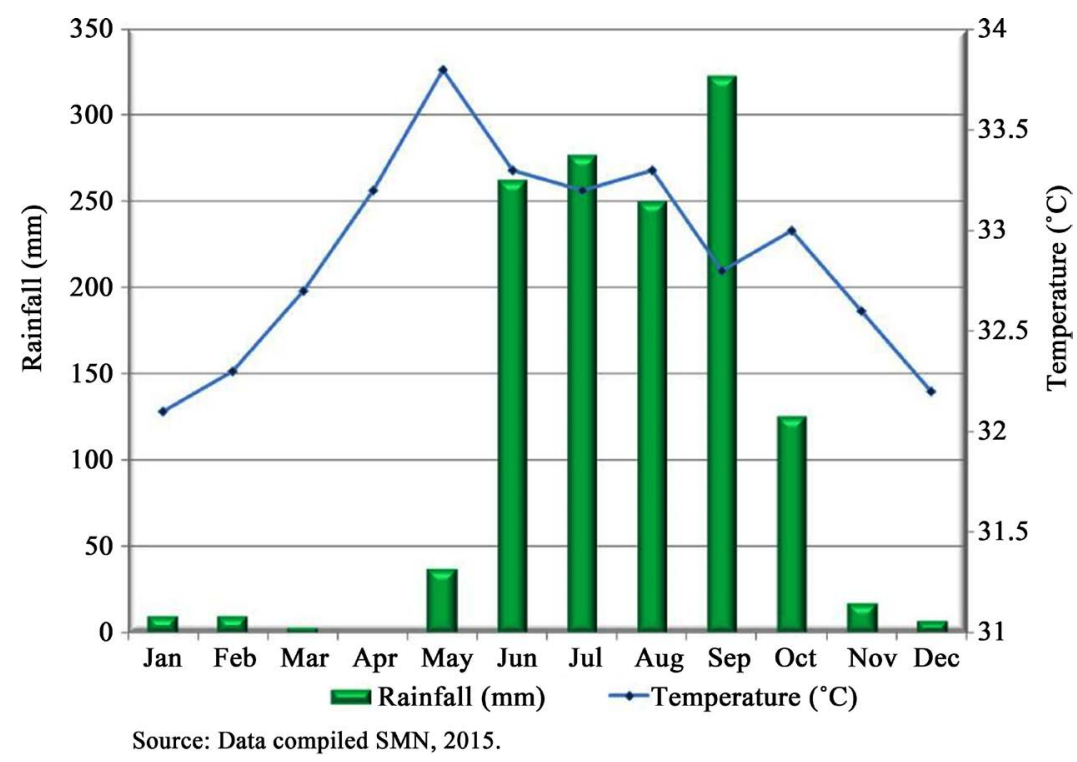

Figure 1. Tecomate lagoon: Temporal variation of temperature and precipitation during the years 1981-2013 (data represent mean values).

influenced by continental plate collision.

The lagoon is separated from the sea by a sediment barrier, $19 \mathrm{~km}$ long by $2 \mathrm{~km}$ wide, formed by fluvial transport and marine accumulation. Communication with the sea is through a meandering channel of $7.5 \mathrm{~km}$ with a mouth bar width of $220 \mathrm{~m}$. However, during the rainy season, the water in the streams is trapped by the barrier facing the sea, with the water level in the lagoon rising to 2.5 meters, the level necessary in order to open the communication with the sea. For this reason, the communication of the lagoon with the sea is directly related to precipitation and fluvial runoff. It should be noted that in the period studied, the bar did not open. The communication with the sea enables both the intensification of the system of currents and greater water circulation in the lagoon.

The River Nexpa flowed into Tecomate Lagoon until 1984, and the completion of the construction of the Mexican Revolution Dam, the objective of which was to store water for the agricultural irrigation of the coastal plain. From that year on, the authorities from the municipality of Florencio Villareal opted to close the branch of the river that communicated with Tecomate Lagoon. Currently, the lagoon only receives water flow from a hydrological microbasin of $384 \mathrm{~km}^{2}$, with two temporary tributaries the River Las Vigas and Tecomate Creek (Figure 2). These tributaries provide nutrients to the system and are influenced by the characteristics of the prevailing climate regime in the region.

\subsection{Depth of the Lagoon}

The lagoon is very shallow, with an average annual depth of $0.80 \mathrm{~m}$. Its depth is influenced by the micro-regional precipitation occurring in the summer. A depth of 0.50 to $1.60 \mathrm{~m}$ was recorded in November 2011. The greatest depth was found at the center and extreme South East of the system (Figure 3). The lowest depths were registered facing the mouth of the River Las Vigas.

The floodable area, considered as lying beyond the principal banks of the lagoon, has an average area of 102 ha, with the large part found to the East and South of the lagoon. This is the lowest section, while the northern section is limited by a system of rolling hills, which prevent floodable areas from forming. Furthermore, the southern, western and eastern sections are lithologically formed by an alluvial system of deposits from the River Nexpa. To the South, the bar that separates the sea from the lagoon is formed by marine accumulation and prevents the lagoon from maintaining effective communication with the sea.

\subsection{Water Temperature}

During the period studied, the water temperature of Tecomate Lagoon ranged from a maximum $32^{\circ} \mathrm{C}$ and a 


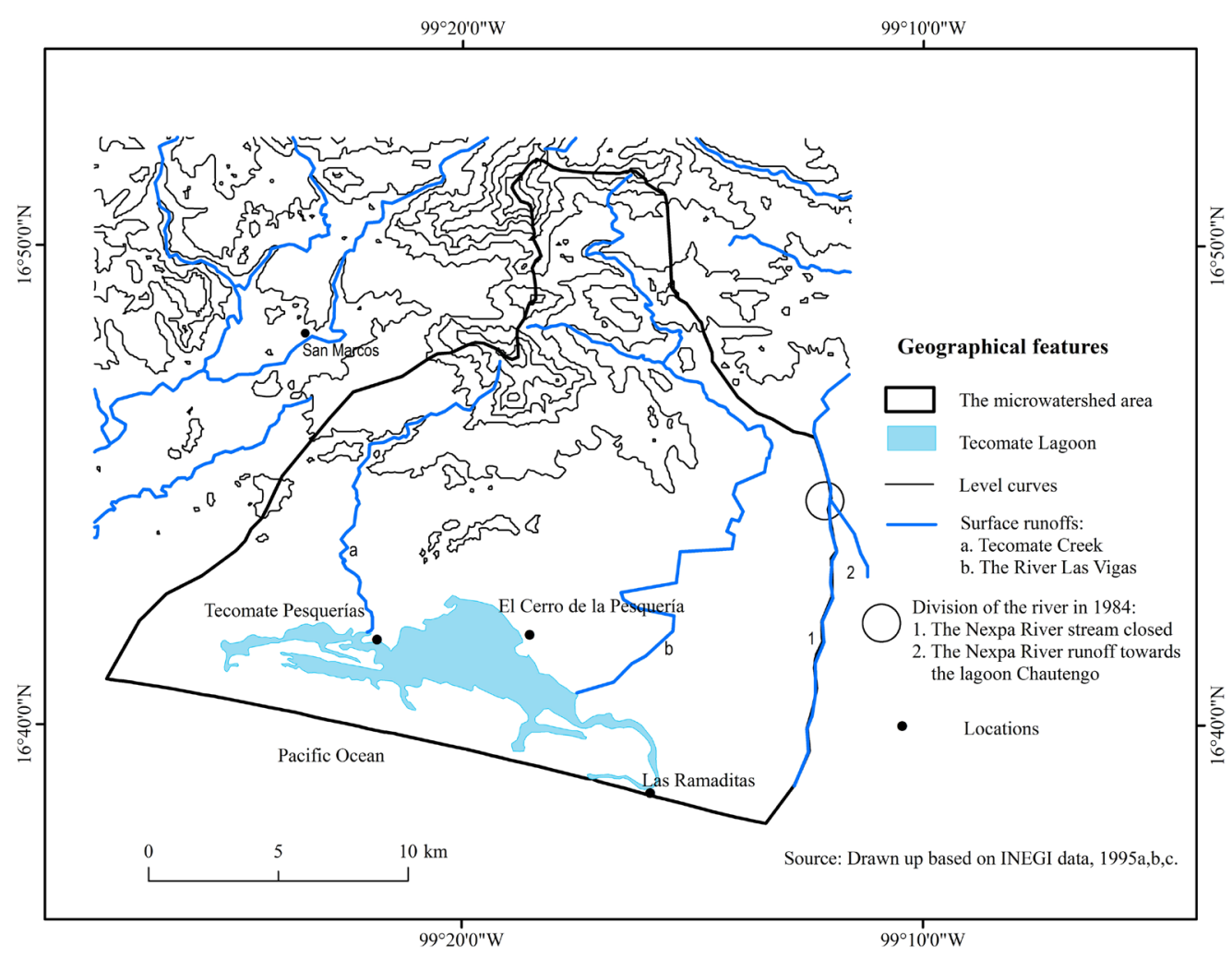

Figure 2. Microbasin catchment and closure of the passage of the river Nexpa to Tecomate lagoon.

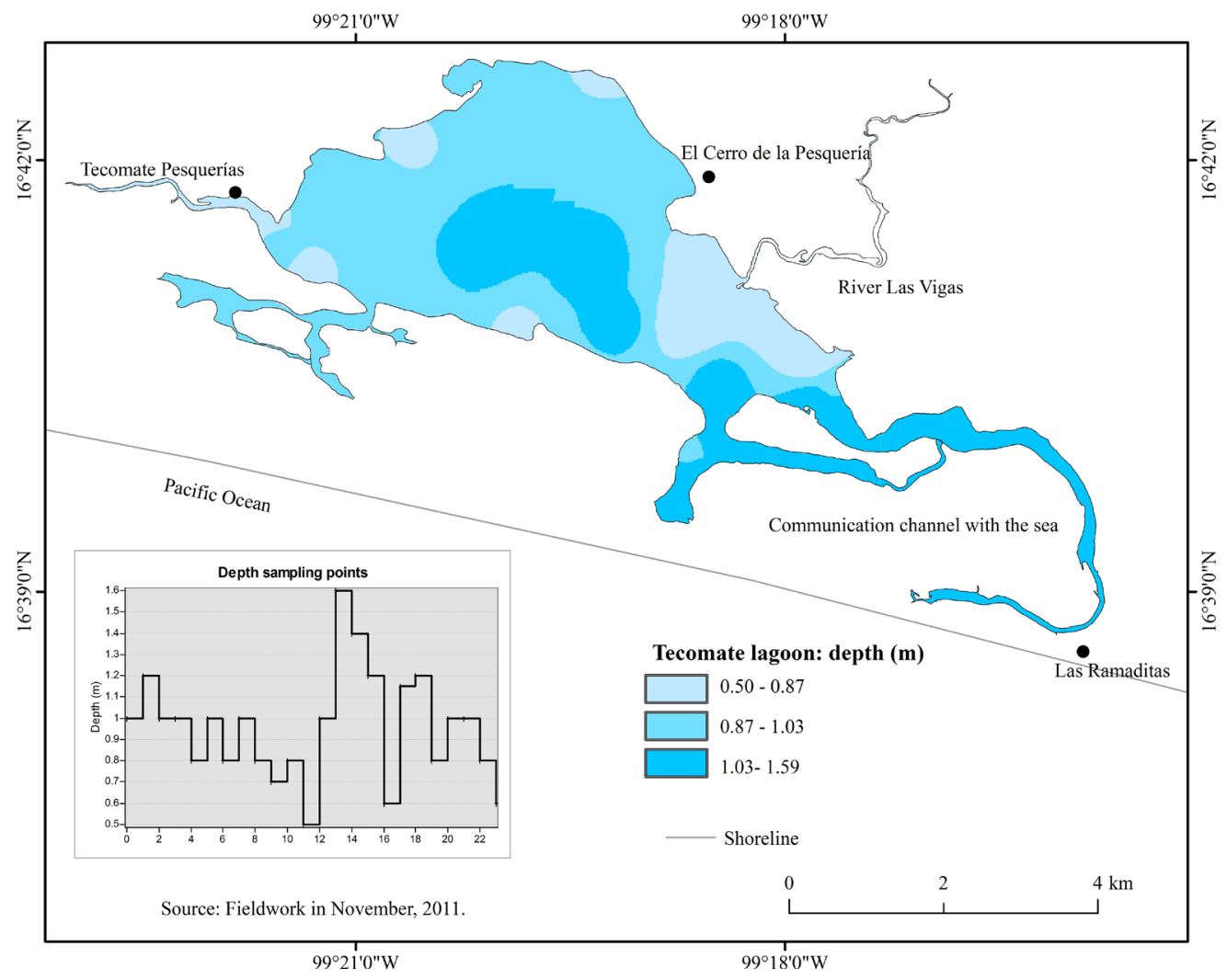

Figure 3. Tecomate lagoon: bathymetry, November 2011. 
minimum $28^{\circ} \mathrm{C}$. In 2011, rain was scarce in the region.

In the months of March, May and August 2012, very high temperatures, ranging from $30^{\circ} \mathrm{C}$ to $32^{\circ} \mathrm{C}$, were recorded. Rain began in May, with runoff water cooling the lagoon to the point where a temperature of $30^{\circ} \mathrm{C}$ was recorded for $70 \%$ of the sampling stations.

The fluvial contribution of the River Las Vigas can be seen in the central part of the lagoon, where the discharge is insufficient for maintaining the water level and regulating the temperature of the system throughout the year, given that discharge depends on micro-regional precipitation.

\subsection{Water Salinity}

Salinity is an important chemical factor in those lagoons that have communication with the sea. This parameter could undergo seasonal variations. Intense evaporation caused by temperature increases lead to an increase in salinity (a higher salt concentration). Secondly, freshwater flows decrease salinity through dilution. In November 2011, the average was 14 ppt. Values of 8.0 to 13.8 ppt were recorded in the North and Northeastern part of the lagoon. The mid-range values were recorded in the central part of the body of water, while maximum values of 15.86 to 20 ppt were recorded in the Southeast area of the lagoon (Figure 4). In November, the increase in salt concentration from the North to the South was caused by the supply of freshwater from fluvial runoff.

In March 2012, the average salinity value was 40.5 ppt. The minimum ranges were from 34.0 to 37.3 ppt. These values follow the same distribution pattern registered in the month of November, while the maximum values were from 40.70 to $47 \mathrm{ppt}$ and were taken at the South of the lagoon. In May 2012, the lagoon became hypersaline, reaching saline concentrations of 42 to 65 ppt (Figure 5). Mid-range salinity was from 48.2 to 56.4

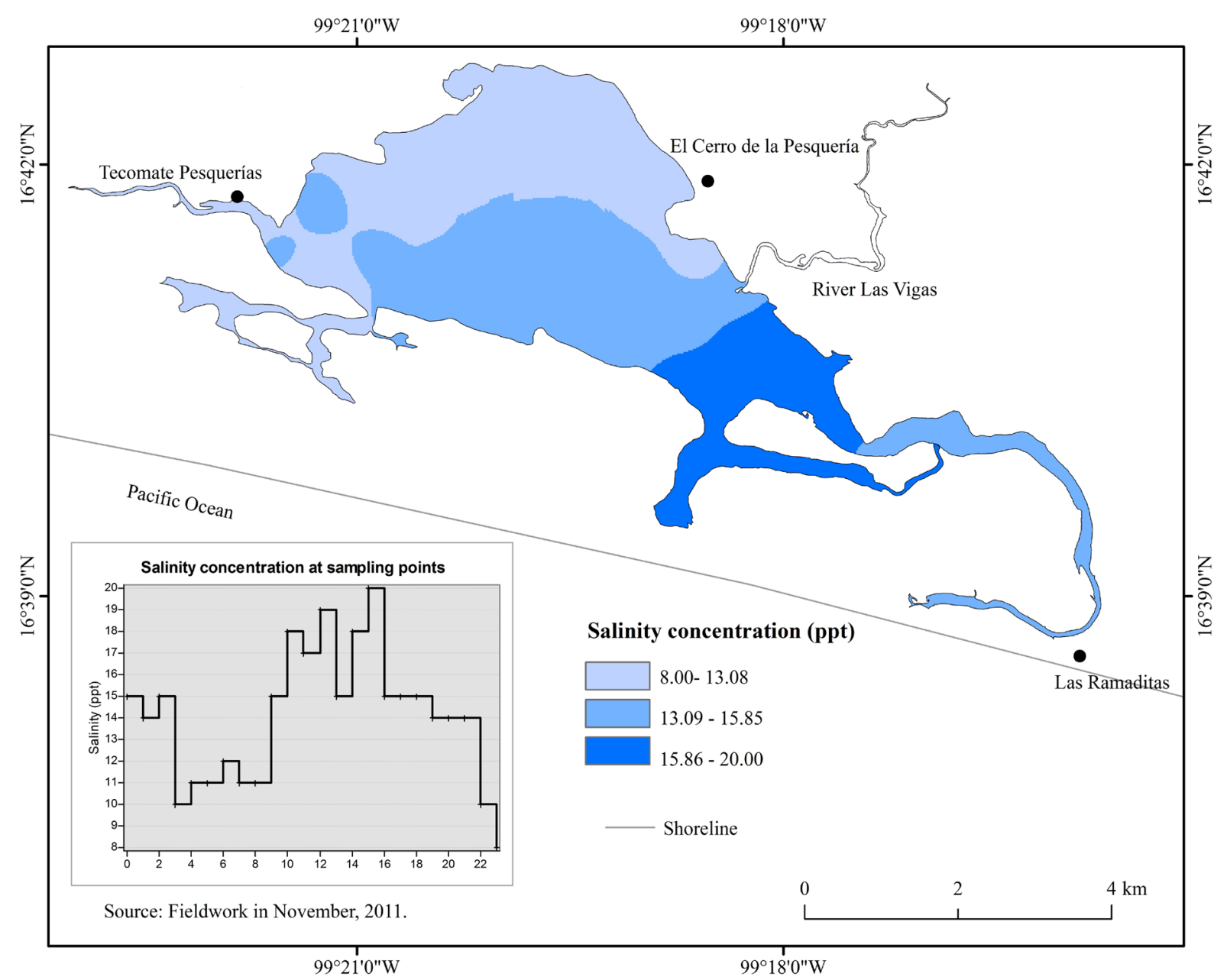

Figure 4. Tecomate lagoon: salinity distribution, November 2011. 


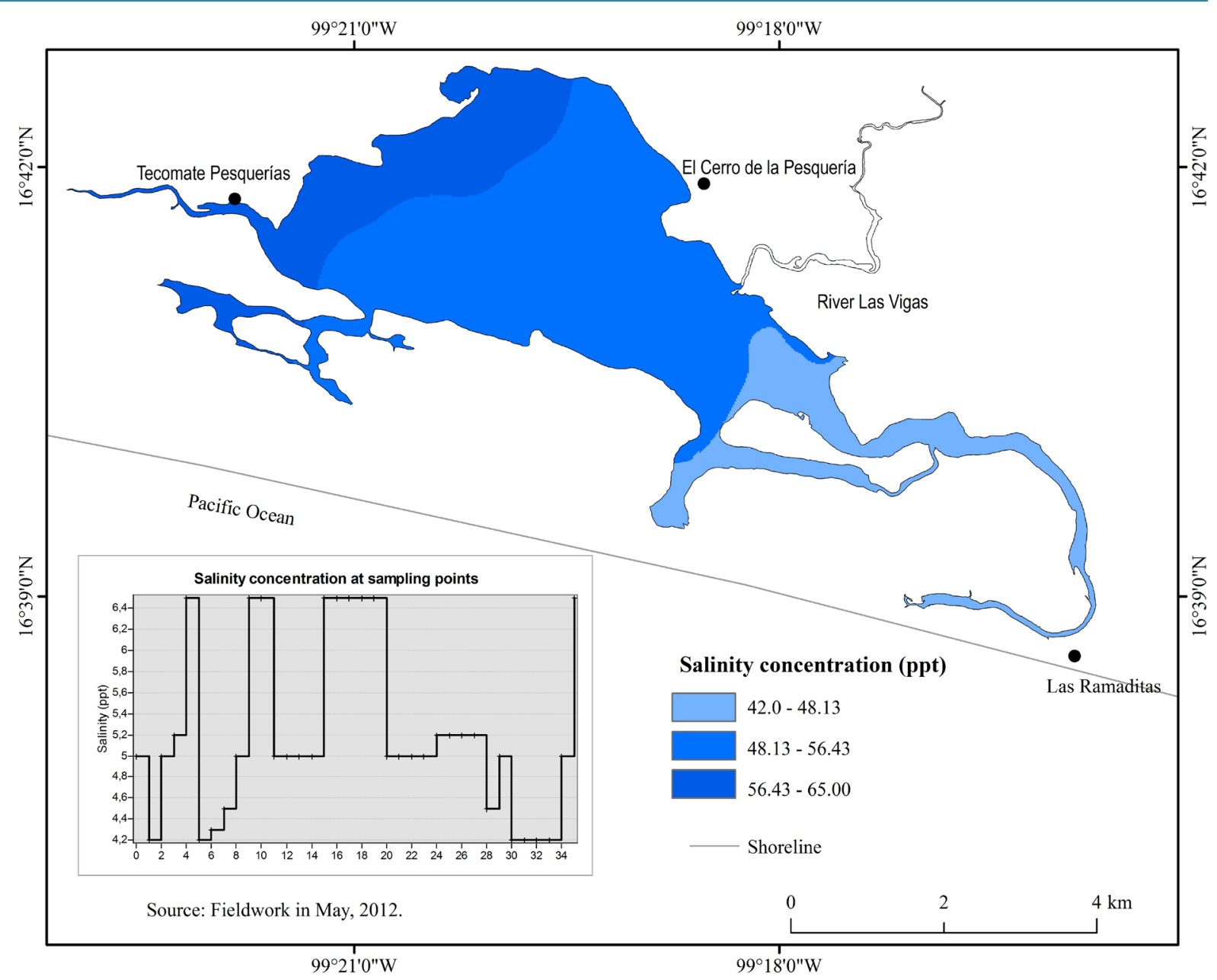

Figure 5. Tecomate lagoon: salinity distribution, May 2012.

ppt, with these readings registered in approximately $70 \%$ of the sampling points in the lagoon. The highest concentration was found in the extreme Southeast, at the beginning of the channel communicating with the sea, and the Northeast, facing the town of Tecomate Pesquerías. The saline concentration increased for these two months due to the increase in water and environmental temperature, as well as the lack of freshwater during the months of low water levels.

During the rainy season in the month of August 2012, the salinity concentration began to decrease. Salinity ranged from 19.0 to $21.9 \mathrm{ppt}$, levels which were observed in the northern part of the lagoon, where the streams discharge runoff. Tecomate Lagoon presents two very contrasting phases of salinity. In the rainy season (June to October), the values for salinity were below $8.0 \mathrm{ppt}$ in certain areas of the lagoon and up to $65 \mathrm{ppt}$ across the large part of the lagoon in the month of May during the period of low water levels. The above conditions make Tecomate Lagoon a body of water with great fluctuations, which can affect aquatic organisms, especially osmoregulation in fish. In interviews, the fishermen mentioned the death of many fish in August 2011, when the lagoon changed from hypersaline to hypohaline, something which had also occurred in other years. The evaluation of the causes of this fish mortality represents an opportunity for future research.

\subsection{Dissolved Oxygen}

During fieldwork, the average annual concentration of dissolved oxygen (OD) was $7.0 \mathrm{mg} / \mathrm{L}$. Representing heterogeneous behavior; the range of variation in OD was from 4.49 to $7.44 \mathrm{mg} / \mathrm{L}$. The lowest concentration of OD $(4.90 \mathrm{ml} / \mathrm{L})$ was recorded in August 2012 in the southeast of the lagoon. OD concentration is sufficient for the growth of ichthyofauna. 


\subsection{Mangrove Forest}

Three species of mangrove are found in Tecomate Lagoon: the white mangrove, Laguncularia racemosa (Linnaeus, 1759); the red mangrove, Rhyzophora mangle (Linnaeus, 1753); and, the black mangrove, Avicennia germinans (Linaeus, 1764). The forest covers an area of 339.34 ha in the lagoon (Figure 6). The distribution of this forest is confined to the banks of this body of water and is reduced to a narrow area of an average of approximately 10 meters. The vegetation presents a well defined ecological succession.

The white mangrove is found in the sections of forest in contact with the water and interacts with the various changes in salinity, temperature and the lack of moisture. It was observed in the dry season that the water level in the lagoon was found at a distance of 15 to 20 meters from the mangrove. The red mangrove is found in the section below the white mangrove. These two associations have been exposed to the various changes with which the lagoon is confronted throughout the year. During the dry season, the foliage of the mangrove changes from green (normal) to a yellowish color symptomatic of a lack of moisture, which indicates the absence of adequate conditions for development. The black mangrove is found at a further distance from the water. This species is grouped in certain areas of the lagoon, principally in the channel and close to the mouth bar.

\subsection{Temporal Variation of Physicochemical Parameters}

A comparison of the measurements in the samples obtained during November 2011 to May 2012 period indicates a great variation in the salinity of 39.03 ppt (Table 1). This could be seen as an important factor requiring further study and a factor that is limiting life in Tecomate Lagoon. On the other hand, data of salinity, tempera-

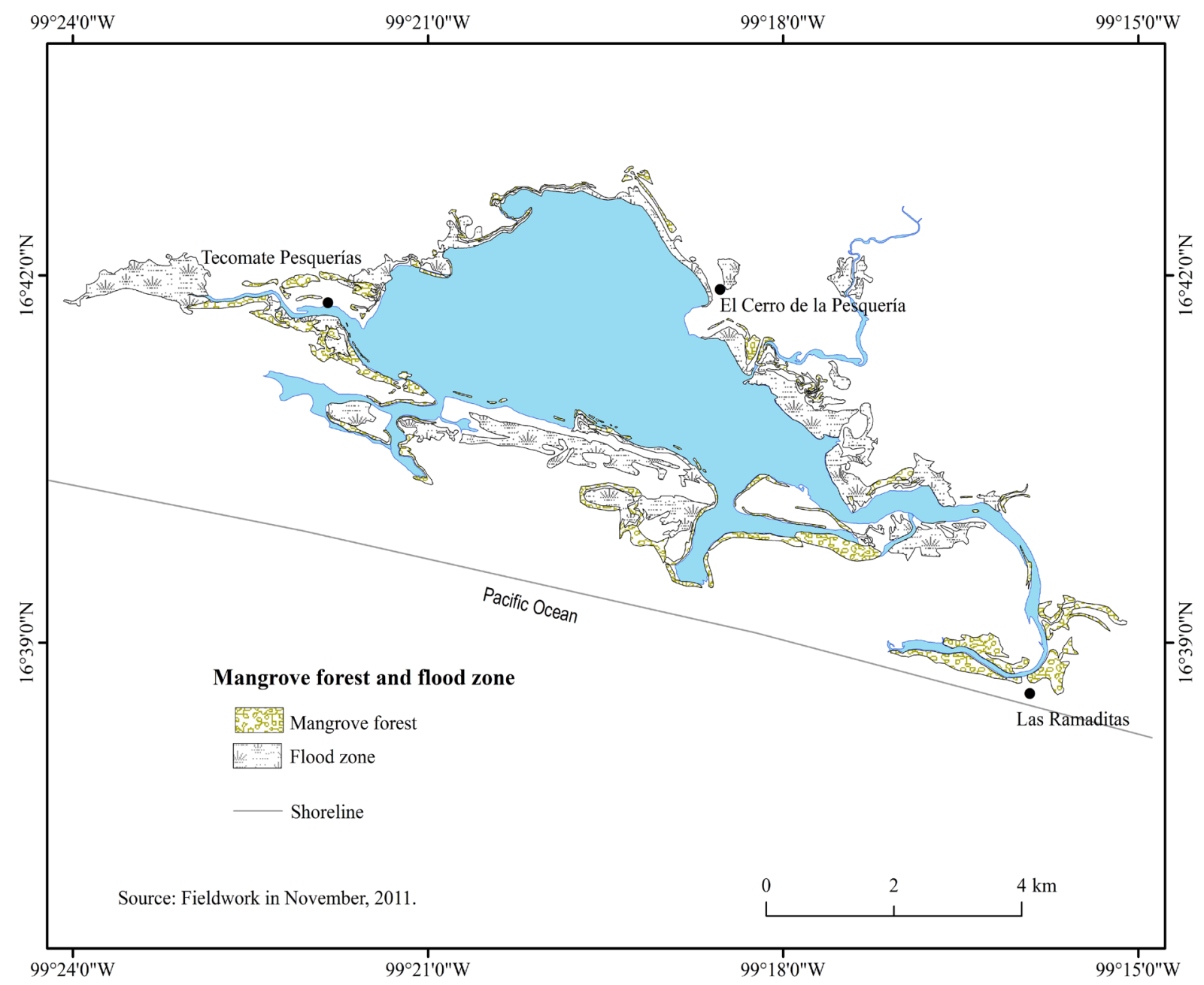

Figure 6. Tecomate lagoon: mangrove forest distribution November, 2011. 
ture, dissolved oxygen and depth, obtained in the four month sampled were analyzed using ANOVA, with the result showing variations within each month and from month to month (Table 2). The depth factor showed greater variation within the each month, while, for the salinity factor, the greatest variation was found from month to month. For the oxygen factor, the greatest variation is found within each month in which the samples were taken, while the greatest variation for the temperature factor was found from month to month. Therefore, the salinity and temperature factors present great variation among the elements found in the samples, but little variation among the measurements for these samples. On the contrary, the greatest variability occurred within the sample for the depth and oxygen factors.

\section{Discussion}

The parameter that presented the greatest variation was the salinity. This parameter varies across different coastal lagoon ecosystems according to depth, tide and freshwater affluence [18] [19]. The salinity of subsurface water found was from 8.00 to 65.00 ppt. Salinity presented heterogeneous spatial-temporal behavior, due to the freshwater flow into the lagoon. In the rainy season, from June to October, the lagoon becomes oligohaline, while in the low water season, from November to May, salinity increased and the water became mesohaline, polyhaline and briny. Salinity is an important factor influencing the physiology and reproductive activity of aquatic organisms [19] [20]. Small changes in salinity can affect physicochemical and biological factors in an aquatic ecosystem [21].

The absence of significant discharge of water into the lagoon has caused a very significant hydrodynamic alteration, further to presenting a communication with the sea that depends on the climatic conditions. As indicated by [22], the coastal lagoons of the Mexican Pacific maintain temporary or permanent communication with the sea. A depth lower than 1.60 meters in the month with the highest water level (November) and lower than 1 meter in the dry season (May), and an average annual temperature of $30^{\circ} \mathrm{C}$, indicate that the lagoon system is in

Table 1. Mean values ( \pm variance) of physicochemical parameters registered in Tecomate lagoon during November 2011 to August 2012.

\begin{tabular}{|c|c|c|c|c|}
\hline \multirow{2}{*}{ Sampled months } & \multicolumn{4}{|c|}{ Physicochemical parameters } \\
\hline & Depth (m) & Temperature $\left({ }^{\circ} \mathrm{C}\right)$ & Salinity (ppt) & Disolved oxygen (mg/L) \\
\hline November 2011 & $0.96 \pm 0.05$ & $30.01 \pm 0.70$ & $14.20 \pm 9.68$ & $6.48 \pm 0.96$ \\
\hline March 2012 & $0.82 \pm 0.02$ & $31.80 \pm 0.15$ & $36.97 \pm 7.89$ & $6.63 \pm 1.03$ \\
\hline May 2012 & $0.54 \pm 0.04$ & $31.91 \pm 1.28$ & $53.23 \pm 59.77$ & $7.44 \pm 5.29$ \\
\hline August 2012 & $1.12 \pm 0.16$ & $30.51 \pm 0.42$ & $23.70 \pm 17.18$ & $4.49 \pm 2.67$ \\
\hline Total & $0.86 \pm 0.11$ & $31.06 \pm 1.29$ & $32.03 \pm 24.15$ & $6.26 \pm 0.86$ \\
\hline
\end{tabular}

Table 2. Results of ANOVA for physicochemical parameters sampled in Tecomate lagoon.

\begin{tabular}{|c|c|c|c|c|c|c|}
\hline & leter & Sum of squares & gl & Mean sum of squares & $\mathbf{F}$ & Sig. \\
\hline \multirow{3}{*}{ Depth } & Within each month & 5.44 & 3 & 1.81 & 25.40 & 0.000 \\
\hline & Month to month & 8.28 & 116 & 0.07 & & \\
\hline & Total & 13.72 & 119 & 0.115 & & \\
\hline \multirow{3}{*}{ Salinity } & Within each month & $25,837.49$ & 3 & 8612.49 & 364.42 & 0.000 \\
\hline & Month to month & 2741.43 & 116 & 23.633 & & \\
\hline & Total & $28,578.92$ & 119 & 240.15 & & \\
\hline \multirow{3}{*}{ Oxygen } & Within each month & 141.69 & 3 & 47.23 & 19.26 & 0.000 \\
\hline & Month to month & 284.41 & 116 & 2.45 & & \\
\hline & Total & 426.10 & 119 & 3.58 & & \\
\hline \multirow{3}{*}{ Temperature } & Within each month & 79.99 & 3 & 26.66 & 41.53 & 0.000 \\
\hline & Month to month & 74.47 & 116 & 0.64 & & \\
\hline & Total & 154.46 & 119 & 1.29 & & \\
\hline
\end{tabular}


a state of environmental stress. The minimum and maximum values for temperature went from $28^{\circ} \mathrm{C}$ to $32^{\circ} \mathrm{C}$ in the lagoon.

In studies undertaken at Chautengo Lagoon, which is contiguous to Tecomate Lagoon, the temperature values, $29.3^{\circ} \mathrm{C}$ to $32.9^{\circ} \mathrm{C}$, were very similar for the bar closure period [10]. In the period in which the bar opens, the temperature falls slightly from $31.8^{\circ} \mathrm{C}$ to $28.6^{\circ} \mathrm{C}$ [11] with temperature values between $24.0^{\circ} \mathrm{C}$ and $34.0^{\circ} \mathrm{C}$ and the highest temperature registered for the March to November period [12]. The elevated water temperature changes the physical properties, and, in consequence, generates changes in the metabolism, nutrition and growth of the organisms inhabiting the lagoon.

Mangroves are a vegetation of transcendental importance in the functioning of the lagoon ecosystem, and have anthropic uses. However, with the deterioration of the forest caused by the low-moisture conditions, its recovery must be a priority for the environmental services favored by humanity for the mitigation of climate change, as described by [23].

\section{Conclusions}

The water level of Tecomate Lagoon varies greatly over the course of the year, due to the lack of tributaries bringing water to the lagoon system as a result of the closure of the connection with the River Nexpa in 1984. Currently, this is limited to a microbasin of $380 \mathrm{~km}^{2}$ and water runoff in the summer. Salinity is considered a principal factor influencing the natural dynamic of this coastal lagoon ecosystem due to its high level of variation, which affects the growth and succession of species and productivity in general. The values for dissolved oxygen indicate adequate conditions in the lagoon, which enable aquatic organisms to develop their life cycle. However, the variable range of salinity over the course of the year can cause alterations, particularly in oxygen solubility levels (the solubility of oxygen decreases when salinity increases), and can cause changes in the metabolism of the fish.

The mangrove forest is in a clear state of deterioration as a result of evaporation and high saline concentration. It is a forest in a state of stress for six months per year (the dry season), and subsists despite the adverse environmental conditions.

To mitigate the impact of the environmental deterioration undergone by Tecomate Lagoon, it is recommendable that the population settled on the banks of the lagoon and the governmental authorities of the Comisión Nacional del Agua (CONAGUA), establish agreements for the construction of a canal to supply water from the Mexican Revolution Dam to the lagoon, principally in the dry season in the months of January to May.

\section{References}

[1] Chavez-Lopez, R., Franco-Lopez, J., Moran-Silva, A. and O’Connell, M.T. (2005) Long-Term Fish Assemblage Dynamics of the Alvarado Lagoon Estuary, Veracruz, Mexico. Gulf and Caribbean Research, 17, 145-156. http://dx.doi.org/10.18785/gcr.1701.15

[2] Raz-Guzman, A. and Huidobro, L. (2002) Fish Communities in Two Environmentally Diferent Estuarine Systems of Mexico. Journal of Fish Biology, 61, 182-195. http://dx.doi.org/10.1111/j.1095-8649.2002.tb01770.x

[3] Field, C.B., Osborn, J.G., Hoffman, L.L., Polsenberg, J.F., Ackerly, D.D., Berry J.A., Bjorkman, O., Held, A., Matson, P.A. and Mooney, H.A. (1998) Mangrove Biodiversity and Ecosystem Function. Global Ecology and Biogeography Letters, 7, 3-14. http://www.jstor.org/stable/2997693 http://dx.doi.org/10.2307/2997693

[4] Welcomme, R.L. (1985) River Fisheries. Fish Technical Paper 262, FAO, Rome. http://www.fao.org/docrep/003/T0537E/T0537E00.HTM

[5] Whitfield, A.K. (1999) Ichthyofaunal Assemblages in Estuaries: A South African Case study. Reviews in Fish Biology and Fisheries, 9, 151-186. http://link.springer.com.etechconricyt.idm.oclc.org/article/10.1023/A\%3A1008994405375 http://dx.doi.org/10.1023/A:1008994405375

[6] Duggan, I.C. and White, M.A. (2010) Consequences of Human-Mediated Marine Intrusions on the Zooplankton Community of a Temperate Coastal Lagoon. New Zealand Journal of Marine and Freshwater Research, 44, 17-28. http://dx.doi.org/10.1080/00288331003641661

[7] Simier, M., Blanc, L., Aliaume, C., Diouf, P.S. and Albaret, J.J. (2004) Spatial and Temporal Structure of Fish Assemblages in an Inverse Estuary, the Sine Saloum System (Senegal). Estuarine, Coastal and Shelf Science, 59, 69-86. http://dx.doi.org/10.1016/j.ecss.2003.08.002 
[8] Lankford, R. (1977) Coastal Lagoons of Mexico: Their Origin and Classification. In: Wiley, M., Ed., Estuarine Processes, 182-215. http://dx.doi.org/10.1016/b978-0-12-751802-2.50022-9

[9] Escofet, A. (2004) Marco Operativo de macro y mesoescala para estudios de planeación de zona costera en el Pacífico Mexicano. In: Arriaga-Rivera, E., Villalobos, G., Azuz-Adeath, I. and Rosado-May, F., Eds., El Manejo Costero en México, Universidad Autónoma de Campeche, Cetys-Universidad de Quintana Roo, México, 223-233.

[10] Mandelli, E.F. and Vázquez-Botello, A. (1976) Informe de Investigación. Secretaría de Recursos Hidráulicos-Comisión del Río Balsas, Universidad Nacional Autónoma de México-Centro de Ciencias del Mar y Limnología. Estudio sobre el uso de la zona costera de los Estados de Michoacán y Guerrero, México. SRH-UNAM, México. 120 p.

[11] Martínez, A.G. (1978) Distribución y variación estacional del zooplancton en cinco lagunas costeras del Estado de Guerrero. Anales del Centro de Ciencias del Mar y Limnología, 5, 201-214. http://www.biblioweb.tic.unam.mx/cienciasdelmar/centro/1978-1/articulo43.html

[12] Porfirio, M.M. (1996) Contribución al conocimiento de la pesquería y algunos aspectos de la dinámica poblacional de la lisa blanca Mugil curema (Valenciennes 1836) en la Laguna de Chautengo Guerrero. Tesis, Escuela Superior de Ecología Marina, Universidad Autónoma de Guerrero, México.

[13] Bulit, C. and Díaz-Ávalos, C. (2009) Diversity Patterns of Planktonic Ciliates in Chautengo Lagoon, Guerrero, Mexico. Hidrobiológica, 19, 109-118. http://investigacion.izt.uam.mx/rehb/publicaciones/

[14] Rendón-Dircio, J.A., Ponce-Palafox, J.T., Rojas-Herrera, A., Arredondo-Figueroa, J.L., De La Lanza, G. and FloresVerdugo, F. (2012) Morphometric, Hydrodynamic and Physical-Chemistry Water Lagoon Chautengo, Guerrero, Mexico. Bio Ciencias, 4, 25-37. http://biociencias.uan.edu.mx/publicaciones/02-04/biociencias4-3.pdf

[15] INEGI (2000) Orto-Fotografía 1:75000 E14C68c. INEGI, México.

[16] INEGI (2000) Orto-Fotografía 1:75000 E14C69a. INEGI, México.

[17] ESRI (2011) ArcGIS Desktop: Release 10. Environmental Systems Research Institute, Redlands.

[18] García, E. (1964) Modificaciones al sistema de clasificación climática de Köppen, para adaptarlo a las condiciones de la República Mexicana. Instituto de Geografía-UNAM, México.

[19] De la Lanza, E.G., Ortiz, M.A. and Carbajal, J.L. (2013) Hydro-Geomorphological Differentiation of Coastal Systems of the Pacific, Gulf of Mexico and Caribbean Sea. Investigaciones Geográficas, 81, 33-50. http://www.igeograf.unam.mx/sigg/utilidades/docs/pdfs/publicaciones/inves_geo/boletines/81/bol81_art_c.pdf

[20] Rajan, D.S. (2015) Salinity Fluctuations of Upstream and Downstream Waters of Ashtamudi Estuary. International Journal of Fisheries and Aquatic Studies, 2, 326-330. http://fisheriesjournal.com/vol2issue6/Pdf/2-6-77.1.pdf

[21] Dehadri, P.V. (1970) Changes in the Environmental Features of the Zuari and Mandovi Estuaries in Relation to Tides. Proceeding of Indian Academic Science, 72, 68-80. http://link.springer.com/article/10.1007\%2FBF03051741

[22] Contreras, E.F. (1993) Ecosistemas Costeros Mexicanos. Comisión Nacional para el Conocimiento de la Biodiversidad y Universidad Autónoma Metropolitana, Iztapalapa, México.

[23] Yañez-Arancibia, A., Day, J.W., Twilley, R.R. and Day, R.H. (2010) Manglares Frente al Cambio Climático tropicalización global del Golfo de México? In: Yáñez-Arancibia, Ed., Impactos del Cambio Climático sobre la Zona Costera, Instituto de Ecología AC, Texas Sea Grant Program, Instituto Nacional de Ecología-SEMARNAT, México, 91-126. 